\title{
Variance Reason
}

National Cancer Institute

\section{Source}

National Cancer Institute. Variance Reason. NCI Thesaurus. Code C71479.

A cause of a difference between what is expected and what actually occurs, or a cause of an activity that varies from a norm or standard. 